\title{
STUDIES ON THE DEVELOPMENT OF ALTERNATIVE SURFACTANT IN THE FLOTATION OF PHOSPHOROUS BEARING MINERALS FROM FINE IRON CONCENTRATE*
}

\author{
Marcela Gotelip Barbosa ${ }^{1}$ \\ Armando Corrêa de Araujo² \\ Udaya Bhaskar Kodukula ${ }^{3}$
}

\begin{abstract}
Pellets are the main iron input to the blast furnace at ArcelorMittal Lazaro Cardenas iron and steel making facility in Mexico. Pellets are made at this facility using the concentrates generated and shipped from their captive mines viz., Las Truchas, Pena Colorada, Volcan Sonora. The concentrating plants, after grinding the ore to the liberation size, use magnetic separation and flotation to reject the silica, sulphur and phosphorous impurities. At Volcan Sonora Mines, the ore is contaminated with phosphorous minerals, and hence, after magnetic separation, the phosphate minerals are floated using anionic carboxylate collector (sodium oleate). Apart from floating the phosphate minerals, the sodium oleate also has some tendency to smear on the iron bearing mineral surfaces leaving a hydrophobic surface, which is expected to reduce the green pellet strength due to absorption of ultrafine sized air bubbles on these surfaces, and further generate higher levels of dust during the induration process. In order to alleviate this industrial problem, comparative studies were carried out on the concentrates from magnetic separation using reagents from synthetic sarcosinate and carboxylate family collectors. Results have indicated that the sarcosinate family members not only were found as replacement to carboxylate collectors, but also reduce the phosphorous content below the values achieved with oleate, thus have considerable benefits in the downstream steel making process. Based on the results, plant runs are being taken up at Volcan Sonora. In this article, the laboratory results obtained on iron grades and recoveries, and phosphorous rejection using both the reagents are presented.
\end{abstract}

Keywords: Flotation; Phosphorus bearing minerals; Magnetite.

1 Mining Engineer graduated from Universidade Federal de Minas Gerais - Brazil, Research Engineer, Mining and Mineral Processing Research Center, ArcelorMittal Maizières S.A., Maizières-lès-Metz, France.

2 CTO Mining Projects, ArcelorMittal Mining and AM Global Research and Development, Maizièreslès-Metz, France

3 Senior Research Engineer, ArcelorMittal Global R\&D, East Chicago, USA.

* Technical contribution to the $44^{\text {th }}$ Ironmaking and Raw Materials Seminar, $15^{\text {rd }}$ Brazilian Symposium on Iron Ore and $2^{\text {nd }}$ Brazilian Symposium on Agglomeration of Iron Ore, September $15^{\text {th }}$ to $18^{\text {th }}$, 2014, Belo Horizonte, MG, Brazil. 


\section{INTRODUCTION}

Phosphorous is a major contaminant for the vast majority of uses of iron ores especially all related to iron making. The phosphorous removal of such ores can be normally carried through magnetic separation and flotation. Examples of this process can be encountered in the mines of Kiruna-Sweden, Hercules-Mexico and Chador Malu-Iran for the selective separation of apatite from iron oxides [1].

When flotation is used in reverse flotation circuits where the phosphate mineral represents the froth phase, the selection of chemicals has to bear in mind downstream unit processes that may be affected by the reagents.

Fatty acids are widely applied in flotation of phosphate ores mainly because of their high collecting potential and their low price [2]. Conventional fatty acid is successfully used to float apatite from magnetite ore in a reverse flotation plant installed in Mexico. At this plant, the magnetite concentrate is pelletized to produce iron ore pellets. The pelletizing plant started to face problems on the process of green balling where the green ball product did not present requested strength. It believes that the hydrophobicity generated by fatty acids on magnetite grains is one of the major issues impairing the green ball strength [3]. The low green ball strength induces excessive fines generation in the DRI process, jeopardizing the production of direct reduced iron.

The objective of this study is to perform batch flotation tests with the aim of selecting the best "synthetic" phosphate collectors amongst the ones representing the state-ofart in terms of phosphate removal from magnetite ores worldwide [4,5]. The "synthetic" phosphate collectors can be one alternative when fatty acids are the potential cause of harmful effects in pelletizing.

\section{MATERIAL AND METHODS}

\subsection{Materials}

The experimental work is composed by bench flotation tests which were performed with the sample "as received" from the industrial flotation plant in Mexico. The "synthetic" collectors [4] used in the flotation testwork are presented in the Table 1.

Table 1: Synthetic phosphate collectors tested in the study.

\begin{tabular}{|c|c|c|}
\hline Commercial label & Supplier & $\begin{array}{c}\text { Flotation classification } \\
\text { Arkomon SO }\end{array}$ \\
A & B & $\begin{array}{c}\text { Sarcosinate (amphoteric collector, } \\
\text { anionic in character at high pH) }\end{array}$ \\
\hline MD 20544 & C & $\begin{array}{c}\text { Mixture of large chain } \\
\text { collector) } \\
\text { sulfasuccinamates }\end{array}$ \\
\hline AERO 845 & D & sodium used as Fatty acid oleate salt \\
\hline Oleic Acid &
\end{tabular}

The Table 1 depicts two families of collectors often used in phosphate flotation from magnetite ores. These families include the sarcosinates and the sulfossuccinamates. The development of the sarcosinates for flotation of iron ores is a response to the balling difficulties experienced when magnetite concentrates after phosphate flotation are submitted to agglomeration.

\footnotetext{
* Technical contribution to the $44^{\text {th }}$ Ironmaking and Raw Materials Seminar, $15^{\text {rd }}$ Brazilian Symposium on Iron Ore and $2^{\text {nd }}$ Brazilian Symposium on Agglomeration of Iron Ore, September $15^{\text {th }}$ to $18^{\text {th }}$, 2014, Belo Horizonte, MG, Brazil.
} 


\subsection{Methods}

\subsubsection{Chemical Analyses}

X-Ray Fluorescence (XRF) is the method of choice for chemical analysis of the flotation feed and products. Lost on ignition (LOI) at $1000^{\circ} \mathrm{C}$ is performed for each sample generated.

\subsubsection{Mineralogical characterization}

The mineralogy of the flotation feed is investigated by Scanning Electron Microcopy (SEM) and optical microscopy. Liberation study is also performed utilizing the SEM and optical microscopy results.

Satmagan measurements are also performed on the sample to evaluate the magnetite content. Satmagan measures the total magnetic moment of the sample in a high magnetic field thereby measuring the magnetite content in the sample.

\subsubsection{Particle size distribution}

The size analysis of the flotation feed is measured by using the Malvern Mastersize 2000. The equipment uses the technique of laser diffraction to measure the size of particles. It works by measuring the intensity of light scattered as a laser beam passes through a dispersed particulate sample. This data is then analyzed to calculate the size of the particles that created the scattering pattern.

\subsubsection{Flotation tests}

For the development of the experimental work, the flotation tests were performed using a standard Denver D-12 bench flotation cell. The capacity of the cell is 2 liters. The slurry is prepared at $45 \%$ solids and the rotor speed applied is $900 \mathrm{rpm}$. The depressant is then added in the cell at a pre-defined dosage.

The time of depressant conditioning is fixed at 5 minutes. After that, the collector is added and conditioning time is fixed at 2 minutes. The flotation takes place with airflow of 5 liters/minute. No pH adjustments are required, in all the tests performed, the flotation occurs at natural $\mathrm{pH}$.

The froth and non-floated products are collected and dried in a $100^{\circ} \mathrm{C}$ oven for around 12 hours. After drying, the products are weighed to determine the mass recovery. Aliquots of each product are then sent to be chemically analyzed.

\section{RESULTS AND DISCUSSION}

\subsection{Sample Characterization}

The chemical analysis of the flotation feed "as received" is presented in the Table 2.

Table 2: Chemical analysis of flotation feed "as received".

\begin{tabular}{|c|c|c|c|c|}
\hline $\begin{array}{c}\mathrm{Fe} \\
(\%)\end{array}$ & $\begin{array}{c}\mathrm{SiO}_{2} \\
(\%)\end{array}$ & $\begin{array}{c}\mathrm{Ca} \\
\mathrm{O} \\
(\%)\end{array}$ & $\begin{array}{c}\mathrm{Al}_{2} \mathrm{O} \\
3(\%)\end{array}$ & $\begin{array}{c}\mathrm{TiO}_{2} \\
(\%)\end{array}$ \\
\hline 66.4 & 2.24 & 1.45 & 0.24 & 0.10 \\
\hline $\begin{array}{c}\mathrm{MgO} \\
(\%)\end{array}$ & $\begin{array}{c}\mathrm{P} \\
(\%)\end{array}$ & $\begin{array}{c}\mathrm{Mn} \\
(\%)\end{array}$ & $\begin{array}{c}\mathrm{LOI} \\
(\%)\end{array}$ & $\begin{array}{c}\text { Satmagan } \\
(\%)\end{array}$ \\
\hline 0.10 & $\begin{array}{c}0.34 \\
7\end{array}$ & 0.03 & 2.48 & 86.3 \\
\hline
\end{tabular}

* Technical contribution to the $44^{\text {th }}$ Ironmaking and Raw Materials Seminar, $15^{\text {rd }}$ Brazilian Symposium on Iron Ore and $2^{\text {nd }}$ Brazilian Symposium on Agglomeration of Iron Ore, September $15^{\text {th }}$ to $18^{\text {th }}$, 2014, Belo Horizonte, MG, Brazil. 
The particle size analysis of flotation feed is presented in the figure 2. The "as received sample" is very fine with $80 \%$ passing at $30 \mu \mathrm{m}$.

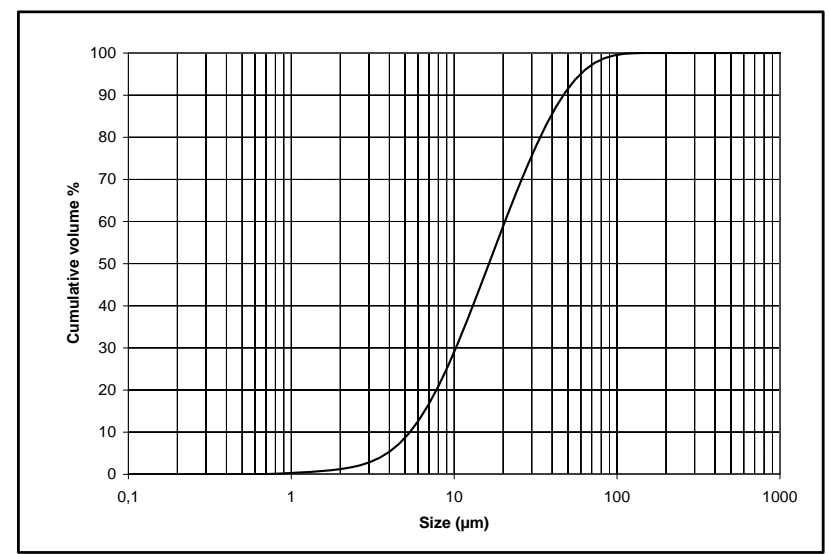

Figure 1: Particle size distribution of flotation feed

The mineralogical characterization was able to provide qualitative analysis of the feed sample. It was identified the presence of iron oxides, as magnetite, iron sulfides, as pyrite and the presence of apatites, as fluorapatite and chlorapatite. Other gangue minerals are also encountered as quartz, calcite and grunerite.

The liberation of the minerals is estimated as $95 \%$ for $-25 \mu \mathrm{m}$ size fraction, $90 \%$ for $35 \mu \mathrm{m}$ and $75 \%$ for $-50 \mu \mathrm{m}$. In the size fraction above $70 \mu \mathrm{m}$, the liberation degree is estimated at $50 \%$ or less.

\subsection{Flotation Results}

The flotation tests presented here below consider the use of $180 \mathrm{~g} / \mathrm{t}$ of collector and $600 \mathrm{~g} / \mathrm{t}$ of depressant. Cornstarch was used as iron oxide depressant in this experimental work.

Table 3 depicts the results obtained for a single rougher flotation test using each collector.

Table 3: First bench flotation tests results.

\begin{tabular}{|c|c|c|c|c|c|}
\hline Collector & Products & $\begin{array}{c}\text { Mass } \\
(\%)\end{array}$ & $\begin{array}{c}\text { Fe } \\
(\%)\end{array}$ & $\begin{array}{c}\mathrm{P} \\
(\%)\end{array}$ & $\begin{array}{c}\text { Fe } \\
\text { recovery } \\
(\%)\end{array}$ \\
\hline Oleic & Concentrate & 90.8 & 67.6 & 0.12 & 92.9 \\
\cline { 2 - 6 } Acid & Tailings & 9.20 & 51.0 & 2.90 & 7.10 \\
\hline Arkomon & Concentrate & 87.5 & 67.9 & 0.05 & 89.9 \\
\cline { 2 - 6 } SO & Tailings & 12.5 & 53.7 & 2.51 & 10.1 \\
\hline MD & Concentrate & 91.4 & 67.7 & 0.08 & 93.2 \\
\cline { 2 - 6 } 20544 & Tailings & 8.6 & 52.5 & 3.37 & 6.80 \\
\hline AERO & Concentrate & 93.7 & 67.3 & 0.15 & 94.8 \\
\cline { 2 - 6 } 845 & Tailings & 6.3 & 54.7 & 2.80 & 5.2 \\
\hline
\end{tabular}

A second battery of flotation tests was performed in the same conditions as the previous one. The objective is to confirm the results obtained. At this time, the two most efficient collectors regarding phosphorus removal were utilized. Table 4 depicts the results obtained in the second battery of bench flotation tests.

\footnotetext{
* Technical contribution to the $44^{\text {th }}$ Ironmaking and Raw Materials Seminar, $15^{\text {rd }}$ Brazilian Symposium on Iron Ore and $2^{\text {nd }}$ Brazilian Symposium on Agglomeration of Iron Ore, September $15^{\text {th }}$ to $18^{\text {th }}$, 2014, Belo Horizonte, MG, Brazil.
} 
Table 4: Second bench flotation tests results.

\begin{tabular}{|c|c|c|c|c|c|}
\hline Collector & Product & $\begin{array}{c}\text { Mass } \\
(\%)\end{array}$ & $\begin{array}{c}\text { Fe } \\
(\%)\end{array}$ & $(\%) \mathrm{P}$ & $\begin{array}{c}\text { Fe } \\
\text { recovery } \\
(\%)\end{array}$ \\
\hline MD & Concentrate & 95.3 & 68.6 & 0.085 & 97.2 \\
\cline { 2 - 6 } 20544 & Tailings & 4.70 & 39.8 & 5.88 & 2.8 \\
\hline $\begin{array}{c}\text { Arkomon } \\
\text { SO }\end{array}$ & Concentrate & 78.6 & 69.9 & 0.036 & 81.2 \\
\cline { 2 - 6 } & Tailings & 21.4 & 59.4 & 1.59 & 18.8 \\
\hline
\end{tabular}

Aiming to investigate the possibility of decreasing the collector dosage, one staged flotation test was performed. The froth was collected 3 times after the addition of $60 \mathrm{~g} / \mathrm{t}$ of collector at each time: $60 \mathrm{~g} / \mathrm{t}, 120 \mathrm{~g} / \mathrm{t}$ and $180 \mathrm{~g} / \mathrm{t}$. The result of the staged test is presented in the Table 5 .

Table 5: Third bench flotation tests results.

\begin{tabular}{|c|c|c|c|c|c|}
\hline Collector & $\begin{array}{c}\text { Concentrat } \\
\text { equality at }\end{array}$ & $\begin{array}{c}\text { Mass } \\
(\%)\end{array}$ & $\begin{array}{c}\mathrm{Fe} \\
(\%)\end{array}$ & $\begin{array}{c}\mathrm{P} \\
(\%)\end{array}$ & $\begin{array}{c}\mathrm{Fe} \\
\mathrm{rec} \\
(\%)\end{array}$ \\
\hline $\begin{array}{c}\text { Arkomon } \\
\text { SO }\end{array}$ & $\mathrm{g} / \mathrm{t} 60$ & 97.0 & $\begin{array}{c}68 . \\
0\end{array}$ & $\begin{array}{c}0.16 \\
8\end{array}$ & 98.3 \\
\cline { 2 - 6 } & $\mathrm{g} / \mathrm{t} 120$ & 92.0 & $\begin{array}{c}68 . \\
8\end{array}$ & $\begin{array}{c}0.05 \\
8\end{array}$ & 94.2 \\
\cline { 2 - 6 } & $\mathrm{g} / \mathrm{t} 180$ & 87.3 & $\begin{array}{c}69 . \\
0\end{array}$ & $\begin{array}{c}0.03 \\
7\end{array}$ & 89.7 \\
\hline
\end{tabular}

Figura 2 illustrates the results of the staged flotation test. The phosphorus removal increases with the decrease of iron recovery, as expected.

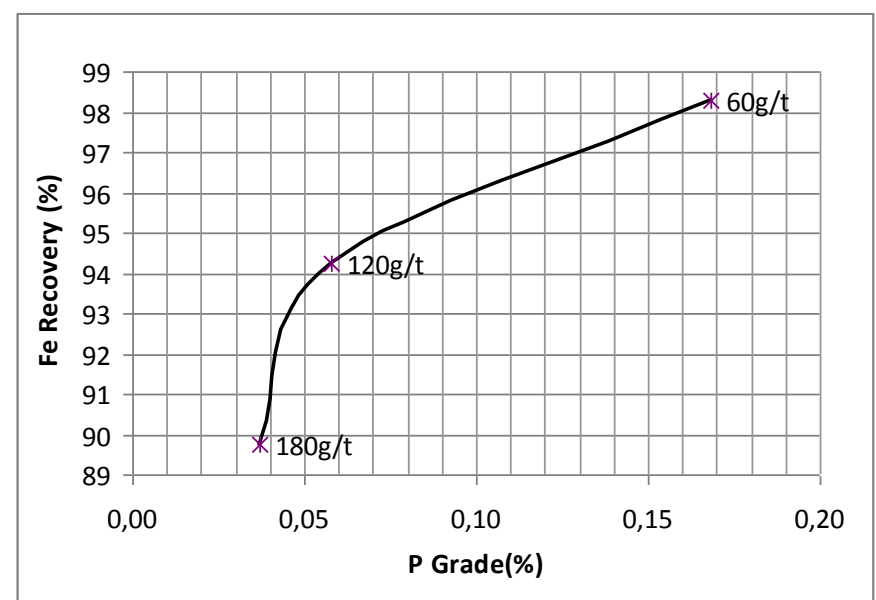

Figure 2: Flotation results showing the $\mathrm{P}$ grade versus iron recovery when Arkomon $\mathrm{SO}$ is used to float phosphates

\subsection{Discussion of Results}

All the tests were performed using as "reference collector" sodium oleate, representing the active constituent in most traditionally used conventional fatty acids collectors. This option was taken because securing samples of the collector currently being used at the plant was not feasible within the period of testing.

The reference test indicates that approximately $71 \%$ of the phosphorus is removed from the sample by reverse flotation technique at an iron recovery level of $92.9 \%$.

* Technical contribution to the $44^{\text {th }}$ Ironmaking and Raw Materials Seminar, $15^{\text {rd }}$ Brazilian Symposium on Iron Ore and $2^{\text {nd }}$ Brazilian Symposium on Agglomeration of Iron Ore, September $15^{\text {th }}$ to $18^{\text {th }}$, 2014, Belo Horizonte, MG, Brazil. 


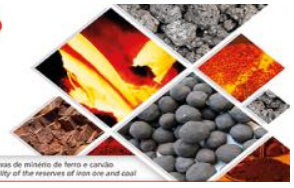

The recovery of total iron is within expected results if one takes into consideration that the test represents only a rougher stage.

The performance of AERO 845 was worse then the one obtained with the reference collector, sodium oleate. No further tests were done employing this collector.

Both Arkomon SO and MD20544 showed interesting results in terms of selectivity and recovery. Phosphate recovery into the froth increased significantly in comparison to the reference collector, reaching a maximum value close to $88 \%$ for Arkomon SO, which would be compared to $71 \%$ with the sodium oleate. Both "synthetic" collectors, Arkomon SO and MD20544 enable the production of final rougher concentrate with total phosphorus level of $0.08 \%$ or less, which should be compared with the $0.12 \%$ obtained with the reference collector.

Regarding the second battery of bench flotation tests, the results obtained were very similar to the ones achieved in the previous tests. The lowest phosphorus grade obtained in the concentrate was $0.036 \%$ using Arkomon SO. This result is even better than the one achieved in the first test.

The third bench flotation test has as objective to evaluate the possibility of decreasing the collector dosage. As presented in the Figura 2, reasonable phosphorus grades are obtained already at $120 \mathrm{~g} / \mathrm{t}$ of collector dosage. This dosage is also favorable to the total iron recovery, which remains extremely high, when there is no need to achieve lower phosphorus grade than $0.05 \%$.

\section{CONCLUSION}

Through this experimental work, it is possible to conclude that a higher phosphorus grade decrease in a reverse magnetite flotation can be achieved by replacing a traditional fatty acid type collector, in this case sodium oleate, by synthetic collectors from the sarcosinate family.

The lowest phosphorus grade achieved in the concentrate was $0.036 \%$ when using Arkomon SO at $180 \mathrm{~g} / \mathrm{t}$ dosage. High iron recovery was maintained during flotation when synthetic collectors were used.

\section{Acknowledgments}

The authors would like to thank the operational engineers at Sonora plant in Mexico who provided the samples required to perform this experimental work. In addition to that, we would like to thank the reagent suppliers Clariant, Akzo Nobel and Cytec for providing the required chemicals.

\section{REFERENCES}

1 Leite AL, Araujo AC, Viana PRM, Henriques AB. 2009, Occurrence of Phosphorusbearing Minerals in Brazilian Iron Ores, Geomin, Antofagast, 254-265A. P. Chaves, "Teoria e Pratica do Tratamento de Minérios, Vol. 4, Flotação, Signus Editora, 2006.

2 Pinto CAF, Yarar B, Araújo AC. 1991, Apatite flotation kinetics with conventional and new collectors, Preprint 91-80, SME Annual Meeting, Denver, Colorado, February 25-28.

3 Forsmo SPE, Forsmo S-E, Björkman BMT, Samskog P-O. Studies on the influence of a flotation collector reagent on iron green pellet properties, Powder Technology, 2008; 182: 444-452.

4 Sis $\mathrm{H}$, Changer $\mathrm{S}$. Reagents used in the flotation of phosphate ores: a critical review, Minerals Engineer, 2003; 16, 577-585.

\footnotetext{
* Technical contribution to the 44 Ironmaking and Raw Materials Seminar, $15^{\text {td }}$ Brazilian Symposium on Iron Ore and $2^{\text {nd }}$ Brazilian Symposium on Agglomeration of Iron Ore, September $15^{\text {th }}$ to $18^{\text {th }}$, 2014, Belo Horizonte, MG, Brazil.
} 